\title{
Recent ice dynamics and mass balance of Jorge Montt Glacier, Southern Patagonia Icefield
}

\section{Paper}

Cite this article: Bown F, Rivera A, Pętlicki M, Bravo C, Oberreuter J, Moffat C (2019). Recent ice dynamics and mass balance of Jorge Montt Glacier, Southern Patagonia Icefield. Journal of Glaciology 65, 732-744. https:// doi.org/10.1017/jog.2019.47

Received: 8 January 2019

Revised: 21 June 2019

Accepted: 24 June 2019

First published online: 28 August 2019

Keywords:

Glacier calving; glacier mass balance; ice velocity

Author for correspondence:

Francisca Bown, E-mail: fbown@cecs.cl (c) The Author(s) 2019. This is an Open Access article, distributed under the terms of the Creative Commons Attribution licence (http:// creativecommons.org/licenses/by/4.0/), which permits unrestricted re-use, distribution, and reproduction in any medium, provided the original work is properly cited.

\author{
Francisca Bown ${ }^{1}$ (D), Andrés Rivera ${ }^{1,2}$ (D), Michał Pętlicki ${ }^{1}$ (D), Claudio Bravo ${ }^{3}$ (D), \\ Jonathan Oberreuter ${ }^{1}$ (D) and Carlos Moffat ${ }^{4}$ (D) \\ ${ }^{1}$ Centro de Estudios Científicos (CECs), Valdivia, Chile; ${ }^{2}$ Departamento de Geografía, Universidad de Chile, \\ Santiago, Chile; ${ }^{3}$ School of Geography, University of Leeds, Leeds, UK and ${ }^{4}$ School of Marine Science and Policy, \\ University of Delaware, Newark, DE, USA
}

\begin{abstract}
The Southern Patagonia Icefield (SPI) withdrawal in recent decades shows contrasting behaviours between adjacent basins. One of the basins with highest volumetric losses is located at northernmost SPI. We refer to Jorge Montt tidewater glacier $\left(48^{\circ} 30^{\prime} \mathrm{S} / 73^{\circ} 30^{\prime} \mathrm{W}, 445 \mathrm{~km}^{2}\right.$ in 2018), which retreated $2.7 \mathrm{~km}$ between 2011 and 2018 and thinned at rates of up to $21 \mathrm{~m} \mathrm{a}^{-1}$ over this period. Based on the retreat record, remote-sensing imagery, field data, a mass-balance model and a calving parameterisation, we attempted to differentiate climatic-induced changes (i.e. surface mass balance) and dynamic responses (i.e. calving fluxes). The surface mass balance reached $-4.15 \mathrm{~km}^{3}$ w.e. $\mathrm{a}^{-1}$ between 2012 and 2017 . When frontal ablation is included, the net mass balance is $-17.79 \mathrm{~km}^{3}$ w.e. $\mathrm{a}^{-1}$. This represents a change of trend compared with modelling estimations of positive surface mass balance prior to 2010. This shift is attributed to higher ablation rates given that accumulation is known to have increased between 1980 and 2015. The available evidence, therefore, indicates that frontal ablation is the main factor, supported by observed rates at Jorge Montt as high as $3.81 \mathrm{~km}^{3}$ w.e. $\mathrm{a}^{-1}$ in 2015 , with ice velocities peaking at $11 \mathrm{~km} \mathrm{a}^{-1}$.
\end{abstract}

\section{Introduction}

The Southern Patagonia Icefield (SPI, Fig. 1) is a temperate ice mass (Warren and Sugden, 1993) that spans the territories of Southern Chile and Argentina, and constitutes most of the land ice stored in South America (Pfeffer and others, 2014). This region has become increasingly important due to its global sea level rise contribution (Rignot and others, 2003; Willis and others, 2012b; Gardner and others, 2013). Most of the ablation zones of the SPI glaciers are retreating with high thinning rates, resulting in lake/fjord expansions, the growth in the number of proglacial lakes, the increasing occurrence of glacial lake outburst floods, massive calving events and landslides in formerly ice-covered areas (Wilson and others, 2016, 2018; Harrison and others, 2018; Lenzano and others, 2018). These trends have been related to tropospheric warming (Rasmussen and others, 2007) and precipitation changes (Carrasco and others, 2008), although climate and ice melt models applied to the area have shown positive mass balances with an increasing trend between 1975 and 2011 (Schaefer and others, 2015).

Because most of the SPI glaciers are calving into fjords or lakes, the trigger for ice retreat has alternatively been attributed to ice dynamics (Mouginot and Rignot, 2015), characterised by ice speed acceleration, longitudinal stretching and ice thinning towards the glacier front, where deep fjords can provide the conditions for the ice to be buoyant. On the other hand, SPI glaciers typically comprise temperate ice (Warren and Sugden, 1993), therefore, when their fast flow tongues approach floatation, their fronts undergo widespread crevassing that is enhanced by the presence of abundant surface meltwater, resulting in rapid terminus disintegration. Under these conditions, the ice front is rarely afloat as a consequence of frequent calving, a process that ultimately controls glacier front changes.

Despite a number of recent studies focussing on frontal, area, velocity and elevation changes (Sakakibara and Sugiyama, 2014; Foresta and others, 2018; Malz and others, 2018), the characteristics of the ice-ocean interface that are thought to modulate retreat rates (including ice thickness near the glacier fronts, subaqueous melt and calving fluxes) are still poorly known in this region. This paper addresses some of these deficiencies, presenting new data from Jorge Montt tidewater glacier $\left(48^{\circ} \mathrm{S} / 73^{\circ} \mathrm{W}\right.$, Fig. 1 ) where ice dynamics has not previously been comprehensively studied. The glacier discharges into a proglacial fjord that is connected to the Pacific Ocean through the Baker channel (Moffat and others, 2018).

There is a long record of Jorge Montt Glacier changes; from a first map dated in 1898, coinciding with the Little Ice Age maximum position (Rivera and others, 2012b), and extending through the second half of the 20th century. These changes have been researched by means of aerial photography, cartography and remote sensing, which have provided increasingly frequent and high-quality scenes in recent years. In this long-term record, three distinct periods of frontal changes have been described: the glacier retreated at a relatively low pace of $140 \mathrm{~m} a^{-1}$ as an average rate between 1898 and 1945, then it maintained a relatively stagnant frontal position between 1945 and 1975 with an average terminus retreat of $23 \mathrm{~m} \mathrm{a}^{-1}$; thereafter, the glacier 


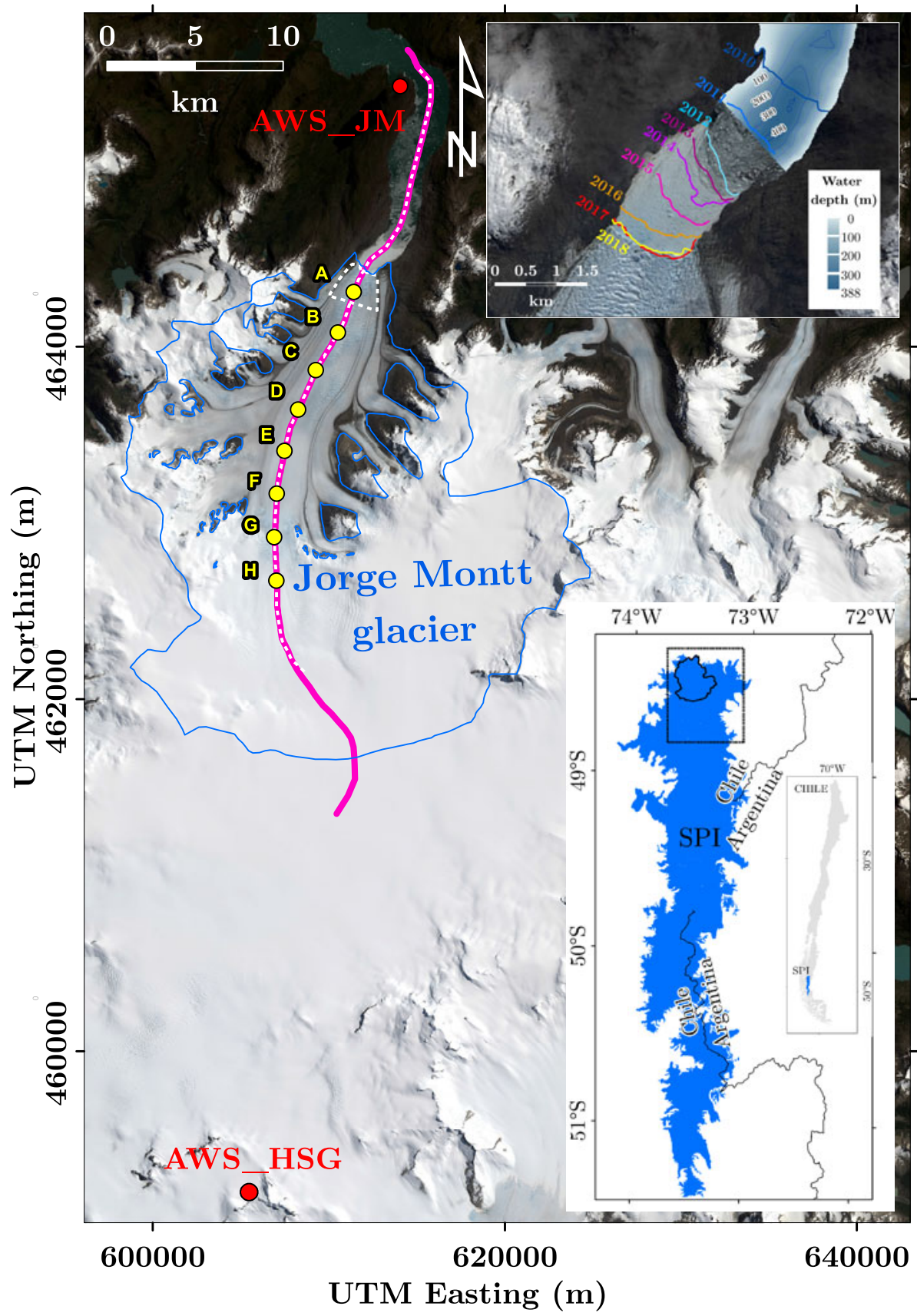

Fig. 1. Delineation of the SPI showing location of study area on the main map. Map of the study area (coordinates in UTM18S, WGS84) includes the glacier outline in 2015 and the calving front area in dashed white outline. Also shown the ice velocity profile overlapping the topographic profile discussed in the text (purple line), AWS sites (red dots), sampling points for velocity surface melt correlation $(\mathrm{A}-\mathrm{H})$. The inset shows frontal variations in 2010-2018 and water depth based on Rivera and others (2012b) and Moffat (2014). Background images: Pansharpen Landsat OLI from 21 January 2015 (location map) and 14 February 2018 (inset). has been continuously retreating, with the strongest retreat period observed in the 1990s, with a total annual rate of $340 \mathrm{~m} \mathrm{a} a^{-1}$ between 1975 and 2018. The enhanced retreat cycles of Jorge Montt during historical times were greatly affected by water depth (Rivera and others, 2012b). Submarine melt together with subglacial discharge, as well as wind forcing, are also thought to play a significant role in the fjord water properties and circulation (Moffat, 2014; Moffat and others, 2018).

This paper analyses the behaviour of tidewater Jorge Montt Glacier during recent decades with emphasis on its calving activity changes. The main aim is to compare these results with a glacier mass-balance model to determine the main factors explaining recent glacier responses.

\section{Methods}

Recent retreat and mass balance of Jorge Mott were assessed with combination of remote sensing and field observation methods: satellite and airborne imagery was used to calculate optical flow and frontal position changes, gravimetric and echosounding data enabled estimation of current and historic ice thickness and water depth, surface mass balance was computed with a simple temperature index model and, finally, calving rate and all relevant mass fluxes were calculated in the respective periods.

\section{Satellite imagery and airborne glacier remote sensing}

We processed and visually analysed a satellite dataset of Landsat (TM, ETM and OLI), ASTER and Sentinel optical images since 1986 (Table 1). In this procedure, we mapped the glacier outlines by manual digitisation of the ice fronts on co-registered images; then frontal change rates were determined by comparing each date position at the central ice flowline. Cross-correlation techniques were applied with available panchromatic (or best resolution) bands by using the COSI-CORR software package (Leprince and others, 2007). This method allowed us to calculate ice velocities between scenes of different dates by measuring relative displacement of surface features. We ran the feature tracking 
Table 1. (1) Optical imagery, (2) surface and subglacial topography and (3) field sensor datasets

\begin{tabular}{|c|c|c|c|}
\hline \# & Sensor or instrument & Pixel size (m) & Acquisition date in MM/DD/YYYY unless indicated otherwise \\
\hline \multirow[t]{5}{*}{1} & ASTER $^{a}$ & 15 (VNIR) & $02 / 22 / 2012 ; 3 / 12 / 2013$ \\
\hline & Landsat TM & 30 (VNIR) & 09/18/1986; 10/04/1986; 04/21/1998; 04/28/1998; 02/11/2011; 02/20/2011; \\
\hline & Landsat $\mathrm{ETM}+{ }^{\mathrm{b}}$ & 15 (PAN) & 08/05/2002; 08/14/2002; 05/13/2003; 05/20/2003; 01/21/2012;02/22/2012 \\
\hline & Landsat OLI ${ }^{\mathrm{b}}$ & 15 (PAN) & $\begin{array}{l}\text { 09/12/2013; 09/28/2013; 03/16/2014; 04/01/2014; 01/14/2015; 01/21/2015; 03/05/2016; 03/12/2016; } \\
\text { 03/15/2017; 03/24/2017 }\end{array}$ \\
\hline & Sentinel- $2^{c}$ & 10 (PAN) & $02 / 14 / 2018 ; 10 / 18 / 2018 ; 10 / 23 / 2018$ \\
\hline \multirow[t]{6}{*}{2} & IGM cartography & 50 & $1974 / 1975$ \\
\hline & SRTM & 30 & $02 / 16 / 2000$ \\
\hline & AST14DMO & 15 & 02/22/2003; 02/22/2012; 03/12/2013; 01/09/2016; 03/16/2017; 10/29/2018 \\
\hline & ASTGTM & 15 & 03/17/2011 \\
\hline & AIRGrav & 30 & May \& Nov 2012 \\
\hline & TanDEM- $X^{d}$ & 125 & $2011 / 2016$ \\
\hline \multirow[t]{3}{*}{$3^{e}$} & $\mathrm{AWS}_{\mathrm{JM}}$ & - & $06 / 01 / 2014$ to $02 / 28 / 2018$ \\
\hline & $\mathrm{AWS}_{\mathrm{HSG}}$ & - & $04 / 01 / 2015$ to $01 / 31 / 2017$ \\
\hline & Echosounding and seismic & - & $2010 / 2013$ \\
\hline
\end{tabular}

${ }^{a}$ Source: Land Processes Distributed Active Archive Center.

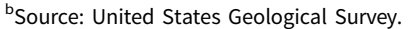

cSource: European Space Agency.

${ }^{\mathrm{d}}$ Source: German Aerospace Center.

eocation in Fig 1.

using the best visual quality and most closely timed scenes (in general weekly to fortnightly) on spatial resolutions not lower than the pixel size of Landsat 5 imagery $(30 \mathrm{~m})$. Only image pairs with correlation coefficients of $\geq 70 \%$ were preserved for the analysis. The calculated velocities were complemented with the freely available Global Land Ice Velocity Extraction from Landsat 8 (GoLIVE) dataset (Fahnestock and others, 2016; Scambos and others, 2016). In comparison with the optical imagery spanning the period 1986-2018 (Table 1), the GoLIVE dataset has a lower spatial resolution $(300 \mathrm{~m})$ but more frequent sampling (every 16 days). We used velocity grids covering the period from 1 May 2013 to 30 April 2017. In addition, our results were compared with those obtained for 1986-2011 with feature tracking techniques by Sakakibara and Sugiyama (2014).

We used several archive sources of the ice elevation records (Table 1): Chile's Instituto Geográfico Militar (IGM) regular cartography based on the aerial photography survey of SPI done in 1975, Shuttle Radar Topography Mission (SRTM) data from year 2000, several ASTER products obtained since 2003 and TanDEM-X data acquired by the German Aerospace Center (DLR) during 2011-2016.

\section{Fjord bathymetry}

Oceanographic cruises carried out by Centro de Estudios Científicos (CECs), the University of Concepción (Chile), the University of Washington (USA) and the University of British Columbia (Canada) have surveyed the fjord development following the glacier retreat since 1898. Water depths and bed characteristics were measured along longitudinal and transverse profiles (Table 1 and Fig. 1). We used echo-sounding and a Datasonics Bubble Pulser sub-bottom profiler acoustics system which allowed the penetration of up to $250 \mathrm{~m}$ of soft sediment deposits (Rivera and others, 2012b). These measurements were extended in 2013 to within a few hundred metres from the glacier front position because ice melange precluded a closer approach to the ice front (Moffat, 2014). Upstream the present glacier front position the subglacial topography was mapped by a combination of radar and aerial gravimetry data collected in recent years (Millan and others, 2019).

\section{Frontal ablation and calving rate}

We calculated the frontal ablation and calving rates of Jorge Montt Glacier for different epochs covering the period 19862018. We used optical satellite imagery separated by short-term periods to obtain ice velocities and a long-term frontal change record, along with various elevation datasets (Table 1) and measurements of ice thickness (Gourlet and others, 2016) and fjord bathymetry (Rivera and others, 2012b) that enabled calculation of a corresponding ice flux.

At San Rafael Glacier (Northern Patagonia Icefield) modelling results show that basal sliding accounts for $98 \%$ of the observed surface ice velocity in the fast-flowing part of the glacier (Collao-Barrios and others, 2018). Following these results, we assume that on Jorge Montt Glacier the vertically averaged ice velocity $\bar{u}_{\mathrm{i}}$ equals the measured surface ice velocity $v_{\mathrm{i}}$ (Pfeffer, 2007). The ice discharge $Q_{i}$ through a fluxgate is calculated by integrating ice velocity $\bar{u}_{\mathrm{i}}$ across a transverse profile:

$$
Q_{\mathrm{i}}=\int_{0}^{L} \bar{u}_{\mathrm{i}}(x) H(x) \mathrm{d} x
$$

where $L$ is the length of the transverse profile, $H(x)$ is ice thickness at glacier width $x$ and is calculated as a difference between surface elevation at, or closest to, a given epoch (IGM, SRTM, ASTGTM) and AIRGrav bedrock elevation (Table 1). The feature tracking algorithm mostly failed to provide reliable results near the ice front, therefore to provide a coherent dataset of ice flow velocity, we used a flux gate located $2 \mathrm{~km}$ up-glacier from a respective frontal position for ice flux calculations. Subsequently, assuming constant flux/mass-conservation along the flow, we calculate 
mean ice velocity at the front $\bar{u}_{\mathrm{f}}$ :

$$
\bar{u}_{\mathrm{f}}=\frac{Q_{\mathrm{i}}}{A_{\mathrm{f}}}
$$

where $A_{\mathrm{f}}$ is the cross-sectional area at the glacier front with ice thickness $H=h+H_{\mathrm{w}}, h$ is ice height above water and $H_{\mathrm{w}}$ is water depth. Subaerial calving rate $\bar{u}_{\mathrm{c}}$ is then calculated as a difference between mean ice velocity at the front and frontal change rate $\partial l / \partial t$ :

$$
\bar{u}_{\mathrm{c}}=\bar{u}_{\mathrm{f}}-\frac{\partial l}{\partial t}
$$

Finally, assuming that on longer timescales submarine frontal ablation follows subaerial calving rate, i.e. frontal ablation rate and calving rate are equal, frontal ablation flux $Q_{\mathrm{f}}$ is calculated as a product of mean calving rate and cross-sectional area at the front:

$$
Q_{\mathrm{f}}=\bar{u}_{\mathrm{c}} \cdot A_{\mathrm{f}}
$$

In this approach, submarine melt is assumed to follow subaerial calving and, therefore, is integrated in the resulting frontal ablation volume, thus its partial contribution cannot be determined. As argued before, ice velocity, calving rate and frontal ablation are assumed to be constant along the vertical profile.

We also analysed some characteristics of calving along the glacier by applying a calving rate parameterisation based on water depth $H_{\mathrm{w}}$ and calving front height $h$ (Mercenier and others, 2018) using bathymetry and gravimetry data:

$$
\begin{aligned}
\bar{u}_{\mathrm{c}}= & \tilde{B}\left(1-\omega^{2.8}\right) \\
& \times\left(\left(0.4-0.45(\omega-0.065)^{2}\right) \rho_{\mathrm{i}} g H-\sigma_{\mathrm{th}}\right)^{r} H
\end{aligned}
$$

where $\tilde{B}=65 \mathrm{MPa}^{-r} \mathrm{a}^{-1}$ is effective damage rate, $\omega=H_{\mathrm{w}} / H$ is relative water level, $\sigma_{\text {th }}=0.17 \mathrm{MPa}$ is a damage threshold stress and $r=$ 0.43 is a damage law exponent. This approach has a solid theoretic foundation that is based on detailed stress analysis and was calibrated on a set of Arctic tidewater glaciers (Mercenier and others, 2018). Therefore, it can be considered as a model that can explain or assess the importance of purely geometric drivers on calving rates. In our case, the subaerial ice cliff height $h$ is assumed a constant $60 \pm 10 \mathrm{~m}$. Water level height $H_{\mathrm{w}}$ is determined by bedrock topography as measured by the bathymetric (Rivera and others, $2012 b$ ) and gravimetric (Gourlet and others, 2016) surveys.

\section{Meteorological data}

Meteorological data were collected using two automatic weather stations (AWS). One AWS was located on a rock outcrop near to Jorge Montt Glacier front $\left(48^{\circ} 15^{\prime} 13^{\prime \prime} \mathrm{S} / 73^{\circ} 27^{\prime} 36^{\prime \prime} \mathrm{W} / 193 \mathrm{~m}\right.$ a.s.l., hereafter $\mathrm{AWS}_{\mathrm{JM}}$, Table 1, Fig. 1) and measured air temperature (sensor Young 41382VC) and precipitation (Young 52202 rain gauge) with 1 hour temporal resolution between June 2014 and February 2018. The second AWS (hereafter AWS $\mathrm{ASG}_{\mathrm{HS}}$, Table 1, Fig. 1) was located further south $\left(48^{\circ} 49^{\prime} 55^{\prime \prime} \mathrm{S} /\right.$ $73^{\circ} 34^{\prime} 53^{\prime \prime} \mathrm{W} / 1428 \mathrm{~m}$ a.s.l.), on a nunatak of Greve glacier. This station provides a continuous air temperature record between April 2015 and January 2017. We used gridded NCEP-NCAR reanalysis data to extrapolate temperature series during years lacking AWS records. Furthermore, the air temperature lapse rate was calculated using a common observation period between measurements at both $\mathrm{AWS}_{\mathrm{JM}}$ and $\mathrm{AWS}_{\mathrm{HSG}}$.

The record of total precipitation measured at $\mathrm{AWS}_{\mathrm{JM}}$ was complemented with NCEP-NCAR reanalysis data (Kalnay and others, 1996) between 2012 and 2017, and extrapolated over the glacier surface. We used the same precipitation gradient of $+5 \% / 100 \mathrm{~m}$ that was used by Schaefer and others (2015), and a threshold temperature for rain and snow of $2^{\circ} \mathrm{C}$, the same as Koppes and others (2011). Daily NCEP-NCAR reanalysis and $\mathrm{AWS}_{\text {JM }}$ precipitation records have a correlation coefficient of 0.62 during the common period (2015-2017). The annualised RMSE of $340 \mathrm{~mm}$ is obtained. Consequently, the uncertainty of the precipitation measurements is estimated at $\sim 15 \%$.

\section{Surface mass-balance terms}

We assumed a simple approach by which the mass accumulation is added through snowfall and that ablation is mainly constrained to surface melt (Cuffey and Paterson, 2010). Due to the temperate regime and high crevassing of the glacier (Warren and Sugden, 1993), both liquid precipitation and surface meltwater are assumed to be drained to the bed (Fountain and Walder, 1998) and subsequently discharged subglacially at the front, forming a buoyant plume (Moffat and others, 2018).

In the absence of solar radiation measurements over the glacier, we applied a simple degree-day model (DDM) relying on air temperature as a single input variable to calculate surface melt (Hock, 2005; Wake and Marshall, 2015) using the closest AWS data. This method has been proven to be suitable in previous studies in the SPI (Takeuchi and others, 1996; Stuefer, 1999; De Angelis, 2014). The DDM is calculated according to this formula:

$$
\sum_{i=1}^{n} M=\mathrm{DDF} \sum_{i=1}^{n} T^{+} \Delta t
$$

where $M$ is the snow and ice melt $\left(\mathrm{mm}\right.$ w.e. $\left.{ }^{\circ} \mathrm{C}^{-1} \mathrm{~d}^{-1}\right)$ in a period $n$ of time interval $\Delta t$ (day), $T^{+}$is the accumulated positive daily air temperatures $\left({ }^{\circ} \mathrm{C}\right)$ and DDF is a degree-day factor.

DDF values for snow surfaces above the local equilibrium line altitude were fixed at $4.92 \pm 1.54 \mathrm{~mm}$ w.e. ${ }^{\circ} \mathrm{C}^{-1} \mathrm{~d}^{-1}$ while in the ablation zone the DDF was $7.17 \pm 1.72 \mathrm{~mm}$ w.e. ${ }^{\circ} \mathrm{C}^{-1} \mathrm{~d}^{-1}$ based on Radić and Hock (2011). The assumption of these DDF values over the entire glacier constitutes the main source of surface melt uncertainty estimated in $\sim 25 \%$ of net surface melt.

\section{Results}

\section{Surface mass balance}

The total specific precipitation for the whole glacier in 2012-2017 (rain+snow) ranges from a minimum of $2.45 \pm 0.37$ to a maximum $2.96 \pm 0.44 \mathrm{~m}$ w.e. $\mathrm{a}^{-1}$. The snow fraction, hereafter accumulation, constitutes $70-80 \%$ of this total yearly received precipitation (Fig. 2), with a resulting range of $1.76 \pm 0.26$ to $2.39 \pm 0.36 \mathrm{~m}$ w.e. $\mathrm{a}^{-1}$. The maximum specific values are $\approx 4.5 \pm$ $0.68 \mathrm{~m}$ w.e. $\mathrm{a}^{-1}$ at the highest elevations around $\sim 1800 \mathrm{~m}$ a.s.l. (see Suppl. Fig. S1) where rainfall is close to $0 \mathrm{~m}$ w.e. At the tidewater front, snowfall reaches between 0.1 and $1 \mathrm{~m}$ w.e. $\mathrm{a}^{-1}$ while rain reaches $\approx 2 \mathrm{~m}$ w.e. $\mathrm{a}^{-1}$. In 2016 particularly low values in snowfall were recorded over the glacier. Total snow accumulation varies between $0.79 \pm 0.12 \mathrm{~km}^{3}$ w.e. $\mathrm{a}^{-1}$ in 2016 and $1.07 \pm$ $0.16 \mathrm{~km}^{3}$ w.e. $\mathrm{a}^{-1}$ in 2017 (Table 2).

$\mathrm{AWS}_{\mathrm{IM}}$ and $\mathrm{AWS}_{\mathrm{HSG}}$ air temperature records are statistically correlated (Fig. 3a). However, the temperature lapse rate shows significant interdaily variability in response to synoptic conditions and thermal inversion episodes. The location of $\mathrm{AWS}_{\mathrm{IM}}$ away from the ice-atmosphere interface is reflected with a milder weather and higher thermal amplitude, with mid-summer temperatures reaching nearly $15^{\circ} \mathrm{C}$. Because the aim was to compute surface melt on a yearly basis, we used the average lapse rate of 


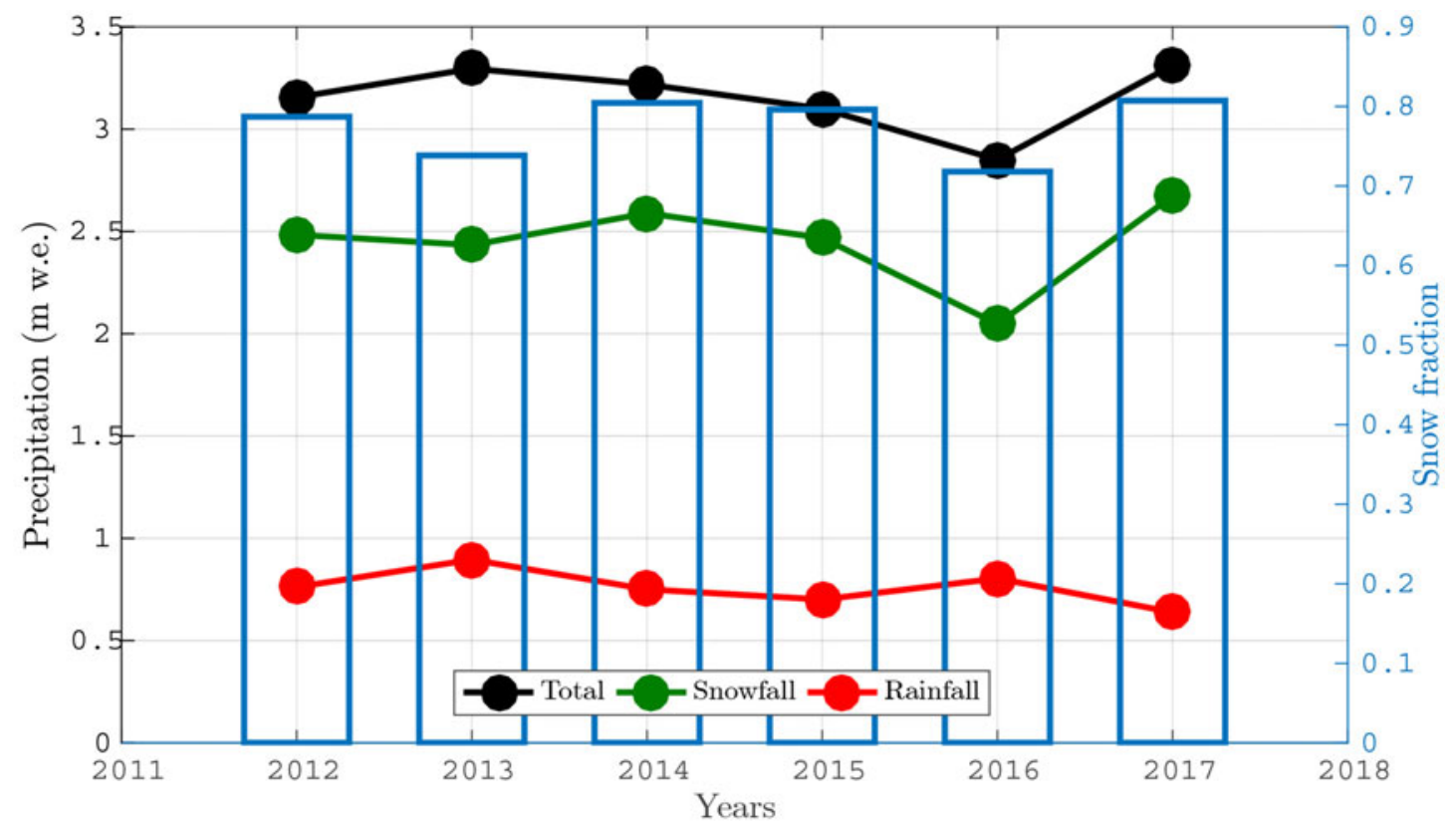

Fig. 2. Snow fraction of total precipitation at Jorge Montt Glacier between 2012 and 2017.

$-0.0058^{\circ} \mathrm{C} \mathrm{m}^{-1}$ (Fig. 3b). Since the NCEP-NCAR $1000 \mathrm{hPa}$ pressure level air temperatures were highly correlated with the $\mathrm{AWS}_{\mathrm{IM}}$ air temperatures (Fig. 3c), we used this NCEP-NCAR dataset to reconstruct the missing period, yielding an average value of $6.97^{\circ} \mathrm{C}$ for the $\mathrm{AWS}_{\mathrm{IM}}$ air temperatures. The resulting 2012-2017 air temperature series, corrected by the cooling effect over the glacier boundary layer (Carturan and others, 2015; Bravo and others, 2019b) assuming a $1^{\circ} \mathrm{C}$ reduction bias, is shown in Figure $3 \mathrm{~d}$. The distributed temperature model for the glacier shows a warmer area comprising the lower outlet tongue and a second area comprising the ice plateau where stronger winds and ice-atmosphere cooling feedbacks are evident (Fig. 3e). The highest surface melt rates are produced in the lowest-elevation glacier area; below $200 \mathrm{~m}$ a.s.l. (Fig. 4a), with values reaching $16-18 \mathrm{~m}$ w.e. $\mathrm{a}^{-1}$. Melt is nearly negligible at $\sim 1300 \mathrm{~m}$ a.s.l. The distributed surface melt between 2012 and 2017 ranges from $1.43 \pm 0.36$ to $1.98 \pm 0.50 \mathrm{~km}^{3}$ w.e. $\mathrm{a}^{-1}$ in 2016 , with a mean value of $1.66 \pm 0.41 \mathrm{~km}^{3}$ w.e. $\mathrm{a}^{-1}$ (Table 2, Fig. $4 \mathrm{~b}$ ).

\section{Frontal variations}

Between 2011 and 2018, the calving front of Jorge Montt Glacier retreated at rates between 640 and $200 \mathrm{~m} \mathrm{a}^{-1}$ (Fig. 1), totalling a net change of $-2.7 \mathrm{~km}$. This implies that $5.2 \mathrm{~km}^{2}$ of ice area was lost in this 7-year period. The maximum retreat rate $\left(640 \mathrm{ma}^{-1}\right)$ was observed in 2011-2012, when the fjord was covered by an ice melange and when an expansion of large crevasses in most of the calving front was observed. The retreat continued at lower rates between 2012 and $2014\left(200 \mathrm{~m} \mathrm{a}^{-1}\right.$ in 2012-2013 and $323 \mathrm{~m} a^{-1}$ in 2013-2014) despite a large ice break-off event that impacted the calving front according to the satellite image acquired on 1 April 2014. Thereafter, the retreat increased to $560 \mathrm{~m} \mathrm{a}^{-1}$ in 2014-2015 and $511 \mathrm{~m} \mathrm{a}^{-1}$ in 2015-2016, when the glacier was highly crevassed down to the calving front. Subsequently, the retreat rate first decreased to $333 \mathrm{~m} \mathrm{a}^{-1}$ in 2016-2017 before the ice front position fully stabilised between 2017 and 2018 (Fig. 1).

\section{Surface ice velocity patterns}

Over the entire glacier record, ice velocities increase from the accumulation zone where minimum values were $\approx 0.5 \mathrm{~km} \mathrm{a}^{-1}$ towards the calving front and where maximum values reached $\approx 10 \mathrm{~km} \mathrm{a}^{-1}$. The ice flow increases from the plateau into the outlet glacier ( $\sim 28 \mathrm{~km}$ from 1986 ice front, Fig. 5). Therefore, extended crevasses surrounding the equilibrium line are observed in the optical satellite imagery (Fig. 1) as ice topography drops from $1300 \mathrm{~m}$ a.s.l. (Fig. 6) down to the lower tongue. There is a second zone of highly extensional flow in the terminal part of the glacier, where ice velocities reach maximum values. A strong increase in ice flow velocity was observed from 1986 to 1998 in the lowermost kilometres of the glacier, followed by relatively stable flow in 2002/03 and then again accelerating velocities in 2011 (Fig. 5). Simultaneously, the surface topography of the whole ablation zone (approximately below $1300 \mathrm{~m}$ ) has been thinning at high rates, with annual values ranging from $-3 \mathrm{ma}^{-1}$ to $-20 \mathrm{~m} \mathrm{a}^{-1}$ at the calving front between 1975 and 2000, and thereafter from $-2 \mathrm{~m} \mathrm{a}^{-1}$ to $-21 \mathrm{~m}^{-1}$ (Fig. 6).

In the majority of the datasets, the feature tracking algorithm failed to provide meaningful results in the area between the ice front and $0.5-1.0 \mathrm{~km}$ upstream, mainly due to extensive ice crevassing in this area and because near the terminus the ice flow is too fast compared with the repeat paths of the satellite imagery. Additionally, the velocity dataset in 2012 is very limited due to the presence of SLC-off gaps in Landsat 7 ETM+ imagery. The maximum ice velocity in 2013 and 2014 was around $4.0 \mathrm{~km} \mathrm{a}^{-1}$ at a position 1-2 km upstream from the calving front. In turn, ice velocity in 2015 reached similar maximum values to those of 1998 $\left(\sim 10 \mathrm{~km} \mathrm{a}^{-1}\right)$ in close proximity to the calving front (Fig. 5). This coincides with a stronger frontal retreat observed in that period. Afterwards, the maximum ice velocities were lower and reached $7.0 \mathrm{~km} \mathrm{a}^{-1}$ in 2016 and $3.5 \mathrm{~km} \mathrm{a}^{-1}$ in 2017 (Fig. 5).

An example of the ice velocity field for the tidewater calving front area (60-200 $\mathrm{m}$ a.s.l., see location in Fig. 1) of Jorge Montt Glacier is shown in Figure 7. There is a marked increase towards the main flowline area from ice margins, comprising both lateral moraines. The part of the glacier that directly reaches the fjord has extremely high velocity values, up to $10-11 \mathrm{~km} \mathrm{a}^{-1}$.

\section{Frontal ablation}

There is a strong increase in frontal ablation from 1986 to 1998, following ice acceleration, when the glacier was retreating rapidly 


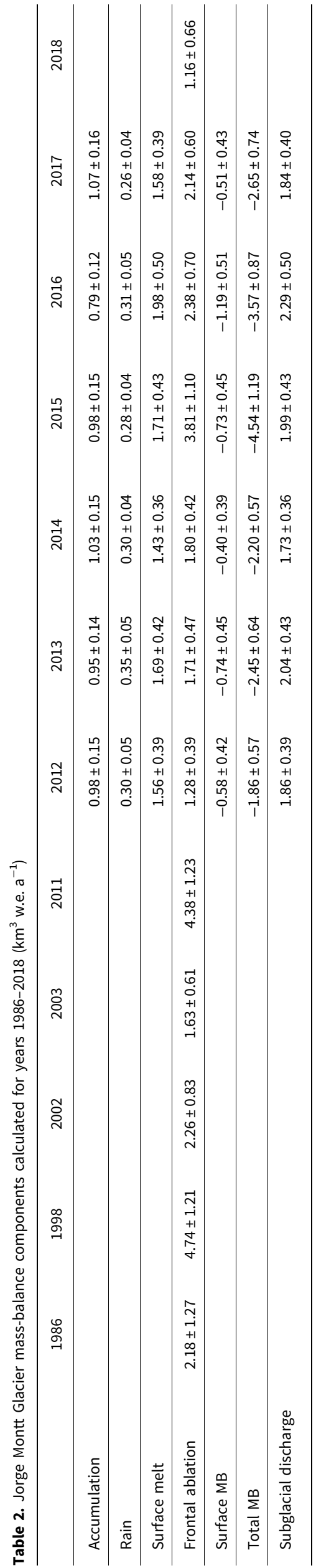

into deep waters (Rivera and others, 2012b). Estimated average ice velocities Eqn (2) together with the subaerial calving rate Eqn (3) yielded a frontal ablation flux Eqn (4) of $4.74 \pm 1.21 \mathrm{~km}^{3}$ w.e. $\mathrm{a}^{-1}$ (Table 2) in 1998 , versus the $2.99 \pm 0.36 \mathrm{~km}^{3}$ w.e. $\mathrm{a}^{-1}$ in the same year based on the parameterisation of Mercenier and others (2018) (Fig. 8). High frontal ablation is observed again in 2011; thereafter there are oscillations, with the highest value in 2015 (Table 2) resulting from larger ice velocities in this latter period.

\section{Mass-balance components partitioning and subglacial discharge}

The total mass balance of Jorge Montt Glacier was consistently negative in years 2012-2017 (Fig. 9). This contrasts with results of Schaefer and others (2015) for 1975-2011 when the surface mass balance was calculated to be slightly positive. Surface melt was significantly lower than frontal ablation in 2015 when the former was $1.71 \pm 0.43 \mathrm{~km}^{3}$ w.e. $\mathrm{a}^{-1}$ and the latter reached $3.81 \pm$ $1.10 \mathrm{~km}^{3}$ w.e. $\mathrm{a}^{-1}$. In other years, both values were almost equal (ratio close to 1 in Fig. 9) within their respective error bounds. Subglacial discharge, calculated as a sum of surface melt and liquid precipitation, remained fairly stable throughout the 20122017 period while oscillating around $2 \mathrm{~km}^{3}$ w.e. $\mathrm{a}^{-1}$, reaching a maximum value of $2.29 \pm 0.50 \mathrm{~km}^{3}$ w.e. $\mathrm{a}^{-1}$ in 2016 and a minimum of $1.84 \pm 0.40 \mathrm{~km}^{3}$ w.e. $\mathrm{a}^{-1}$ in 2017 . At the same period, frontal ablation flux was much more dynamic and resulted in a high variability of the frontal ablation to subglacial discharge ratio (Fig. 9).

\section{Discussion}

In the period 2011-2018, Jorge Montt retreated $2.7 \mathrm{~km}$ (equivalent to an ice area loss of $5.2 \mathrm{~km}^{2}$ ), a process which can be interpreted to have started in 2010, when it was reported the glacier was calving into waters nearly $400 \mathrm{~m}$ deep (Rivera and others, $2012 a$ ). In this process, the calculated ice velocities were the highest values throughout the historical record as compared with datasets for the period 1986-2011, with the sole exception of the peak reached in 1998 (Rivera and others, 2012b). The spatial pattern of ice velocity is consistent across different studies (Muto and Furuya, 2013; Sakakibara and Sugiyama, 2014; Mouginot and Rignot, 2015) and is characterised by minimum velocities in the accumulation zone, ice flow velocity increasing downstream from the plateau into the outlet tongue $(\sim 1200 \mathrm{~m}$ a.s.l. $)$ and strong re-acceleration near the calving front, which in our analysis reached a maximum of $10-11 \mathrm{~km} \mathrm{a}^{-1}$ in 2015 .

Upstream of the present ice front position ice thickness became progressively thinner and $\sim 3 \mathrm{~km}$ from the present ice front, the glacier bed is above sea level (Fig. 6). As a consequence, the recent rates of ice retreat will continue to drive longitudinal stretching with strong ice thinning at least until the ice front stops calving when the glacier bed approaches sea level (Fig. 6).

These calculated ice velocities and frontal changes allowed determination of frontal ablation fluxes in recent decades. In 1998, the frontal ablation reached a maximum of $4.74 \pm 1.21 \mathrm{~km}^{3}$ w.e. $\mathrm{a}^{-1}$, in an area where maximum water depth was higher than $300 \mathrm{~m}$. In recent years, high frontal ablation, somewhat below 1998 value, were obtained with a maximum of $3.81 \pm 1.10 \mathrm{~km}^{3}$ w.e. $\mathrm{a}^{-1}$ in 2015 and a minimum of $1.28 \pm 0.39 \mathrm{~km}^{3}$ w.e. $\mathrm{a}^{-1}$.

These frontal changes and fluxes are accompanied by an overall negative mass balance. Total precipitation specific values between 2012 and 2017 range from $2.45 \pm 0.37$ to $2.96 \pm 0.44 \mathrm{~m}$ w.e. $\mathrm{a}^{-1}$, which if neglecting the liquid phase (as rain percolates and is assumed to be subglacially discharged) drives mass accumulation ranging from $1.76 \pm 0.26$ to $2.39 \pm 0.36 \mathrm{~m}$ w.e. $\mathrm{a}^{-1}$ (Table 2). In turn, the DDM based on common DDF values used in the SPI (Radić and Hock, 2011) and corrections by cooling effects with 

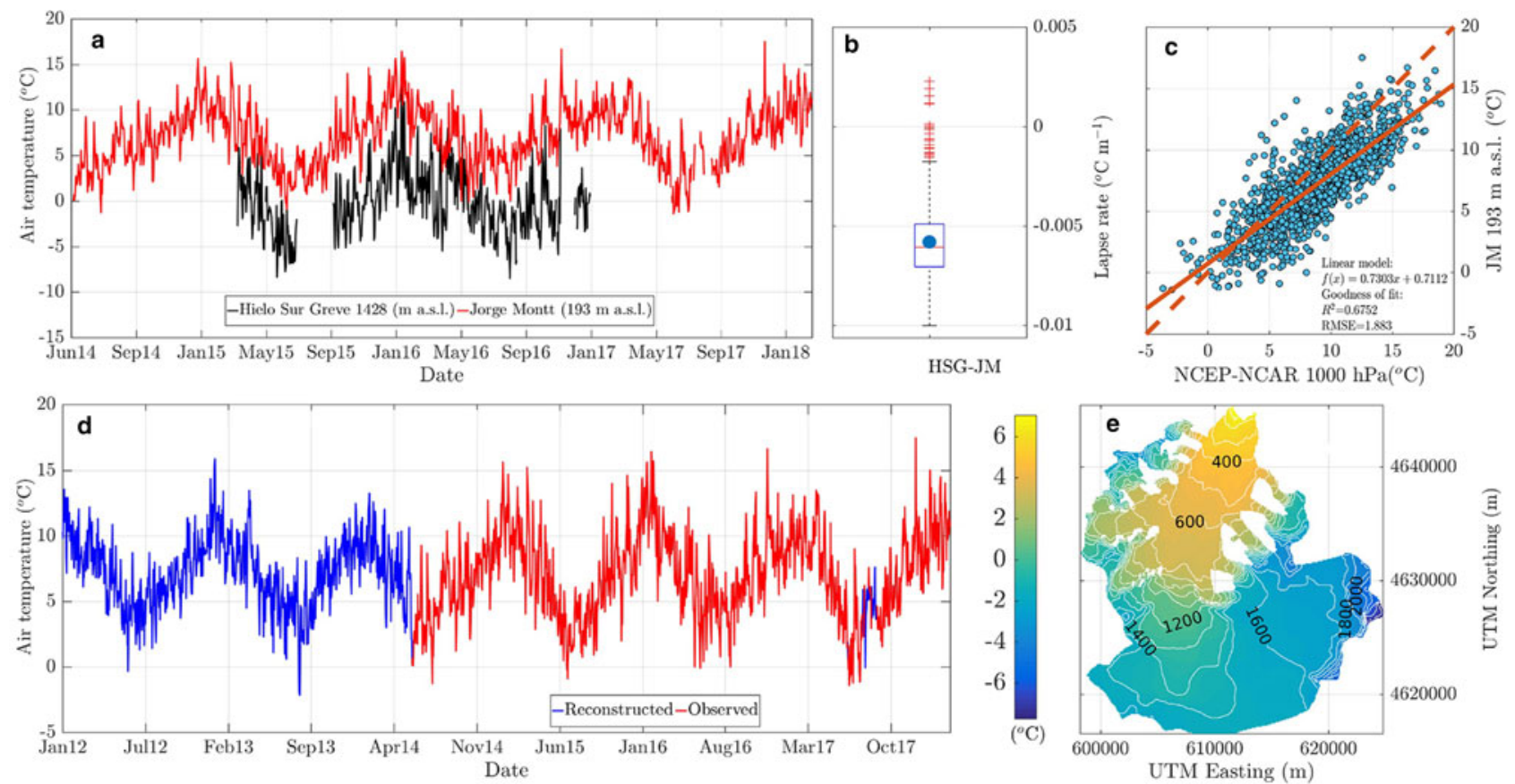

Fig. 3. (a) Observed air temperatures at $A W S_{J M}$ and $A W S_{H S G}$, (b) temperature lapse rate bounded by 75 and $25 \%$ quartiles, red horizontal line and filled circle depicts statistical median and mean, respectively, and crosses are outlier values, (c) mean daily temperature scattering between AWS JM and T1000 (NCEP-NCAR), orange line is the best-fit curve and dashed line is the one-to-one relation, (d) reconstructed AWS $_{\mathrm{JM}}$ air temperatures and (e) distributed air temperatures in January 2012February 2018 after cooling effect correction. Contour lines every $100 \mathrm{~m}$ in white, coordinates in UTM18S, WGS 84.

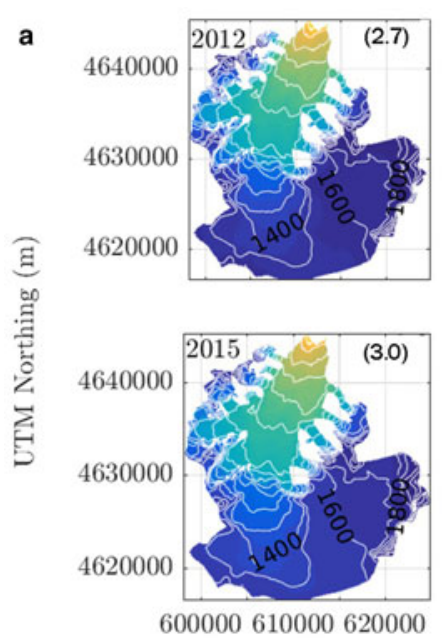

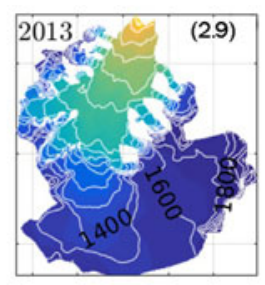

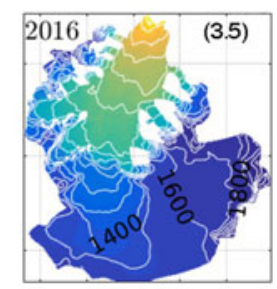

600000610000620000 UTM Easting $(\mathrm{m})$

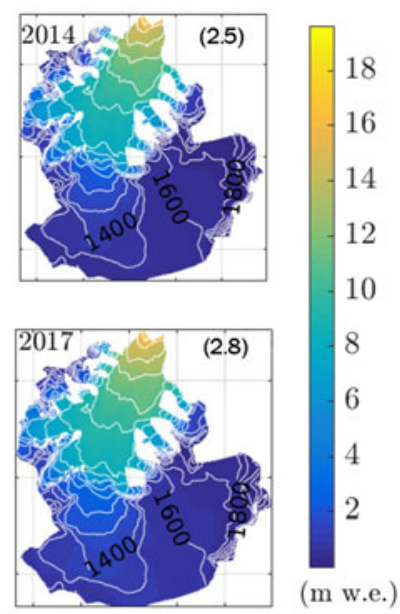

600000610000620000

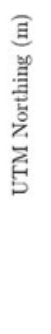

\section{急}

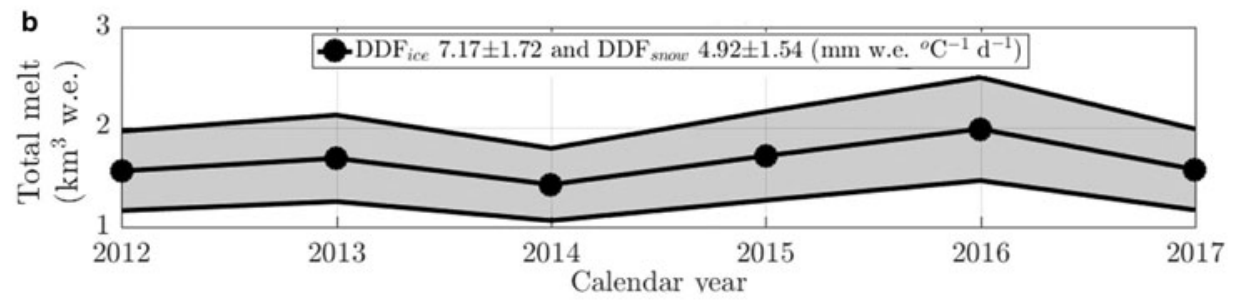

Fig. 4. (a) Distributed surface melt of Jorge Montt Glacier between 2012 and 2017 . Annual mean values in $\mathrm{m}$ w.e. are shown in parentheses. Contour lines every $100 \mathrm{~m}$ in white. (b) Total surface melt in $\mathrm{km}^{3}$ w.e. Coordinates in UTM18S, WGS84.

nearest observations $\left(0.8-1.2^{\circ} \mathrm{C}\right)$, accounts for overall surface melt in 2012-2017 (Table 2) with specific values between $3.19 \pm 0.80$ and $4.42 \pm 1.10 \mathrm{~m}$ w.e. $\mathrm{a}^{-1}$. The severe drought recently recorded in Patagonia (Garreaud, 2018) most likely played a role in explaining these negative surface mass balances, that ranged between $-1.19 \pm 0.51$ and $-0.40 \pm 0.39 \mathrm{~km}^{3}$ w.e. $\mathrm{a}^{-1}$ (Table 2,
Suppl. Fig. S2), or if averaged over the glacier area, between $-2.65 \pm 1.13$ and $-0.89 \pm 0.87 \mathrm{~m}$ w.e. $\mathrm{a}^{-1}$. The mean value for 2012-2017 of $-1.54 \pm 0.98 \mathrm{~m}$ w.e. $\mathrm{a}^{-1}$ indicates a negative shift when compared with downscaling modelling that yielded $0.8 \mathrm{~m}$ w.e. $\mathrm{a}^{-1}$ surface mass balance between 1980 and 2010 (Schaefer and others, 2015). By adding the frontal ablation, the total 


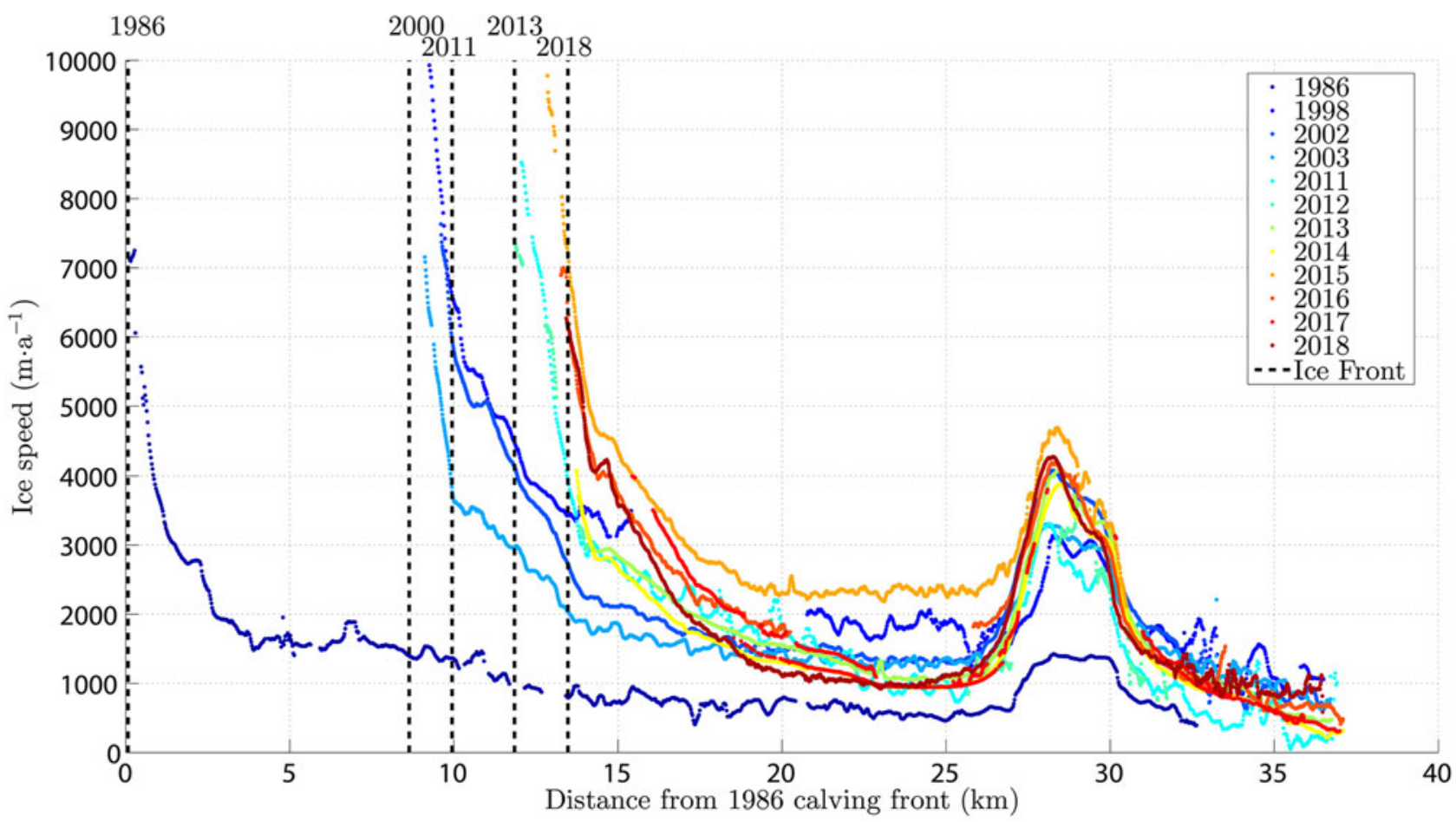

Fig. 5. Jorge Montt surface ice velocities along the central flowline (1986-2018) and frontal positions (dashed lines) based on Rivera and others (2012b) for 19862010 and this work for 2013-2018.

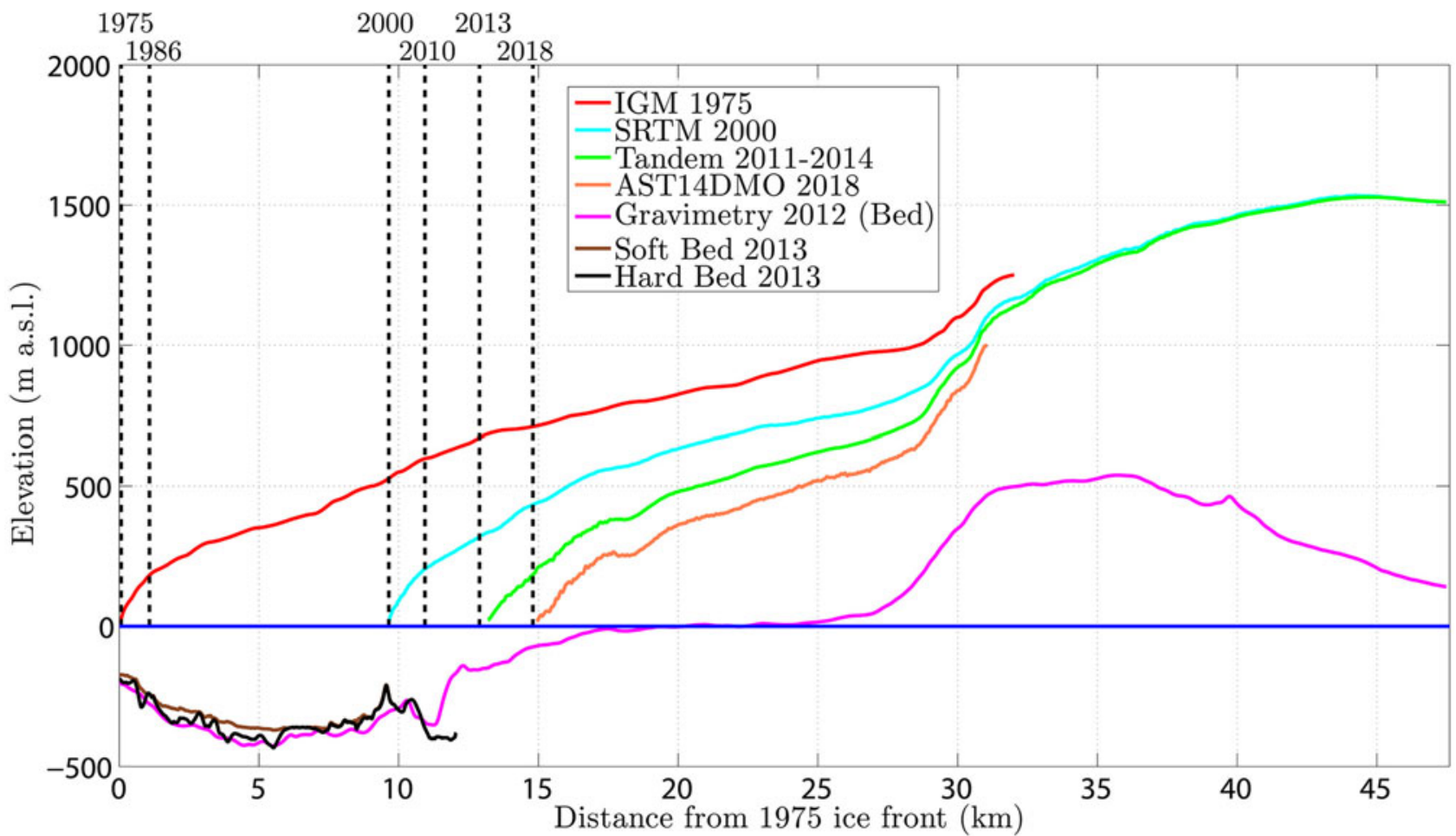

Fig. 6. The geometry of Jorge Montt Glacier in recent decades: ice elevation data from the 1975 Instituto Geográfico Militar official cartography (red), Shuttle Radar Topography Mission for 2000 (cyan), TanDEM Mission for 2011-2014 (green) and AST14DMO for 2018 (orange), ice bed from Gourlet and others (2016) for 2012 (purple), ice front positions (dashed vertical lines) based on Rivera and others (2012b) for 1986-2010 and this work for 2013-2018. Soft bed (brown) is the bathymetry where sediments have been mapped and hard bed (black) refers to the bedrock underlying soft sediment deposits, both surveyed with a sub-bottom Bubble Pulser profiler in 2013.

glacier mass balance of Jorge Montt ranges from $-1.86 \pm 0.57$ to $-4.54 \pm 1.19 \mathrm{~km}^{3}$ w.e. $\mathrm{a}^{-1}$ (Table 2), or $-10.12 \pm 2.65$ to $-4.15 \pm 1.27 \mathrm{~m}$ w.e. $\mathrm{a}^{-1}$. This highly negative total mass balance, consistent with the ice volume losses observed by the geodetic method (Rignot and others, 2003; Willis and others, 2012a; Abdel Jaber and others, 2017; Willis and others, 2012b; Foresta and others, 2018), reveals a much larger importance of frontal ablation than previously thought. A simple comparison of our 
Fig. 7. Ice velocities in the terminal part of Jorge Montt Glacier in the period 14-21 January 2015. Background: Pansharpen Landsat OLI scene from 21 January 2015, coordinates in UTM18S, WGS84. Bi-spline interpolation applied.

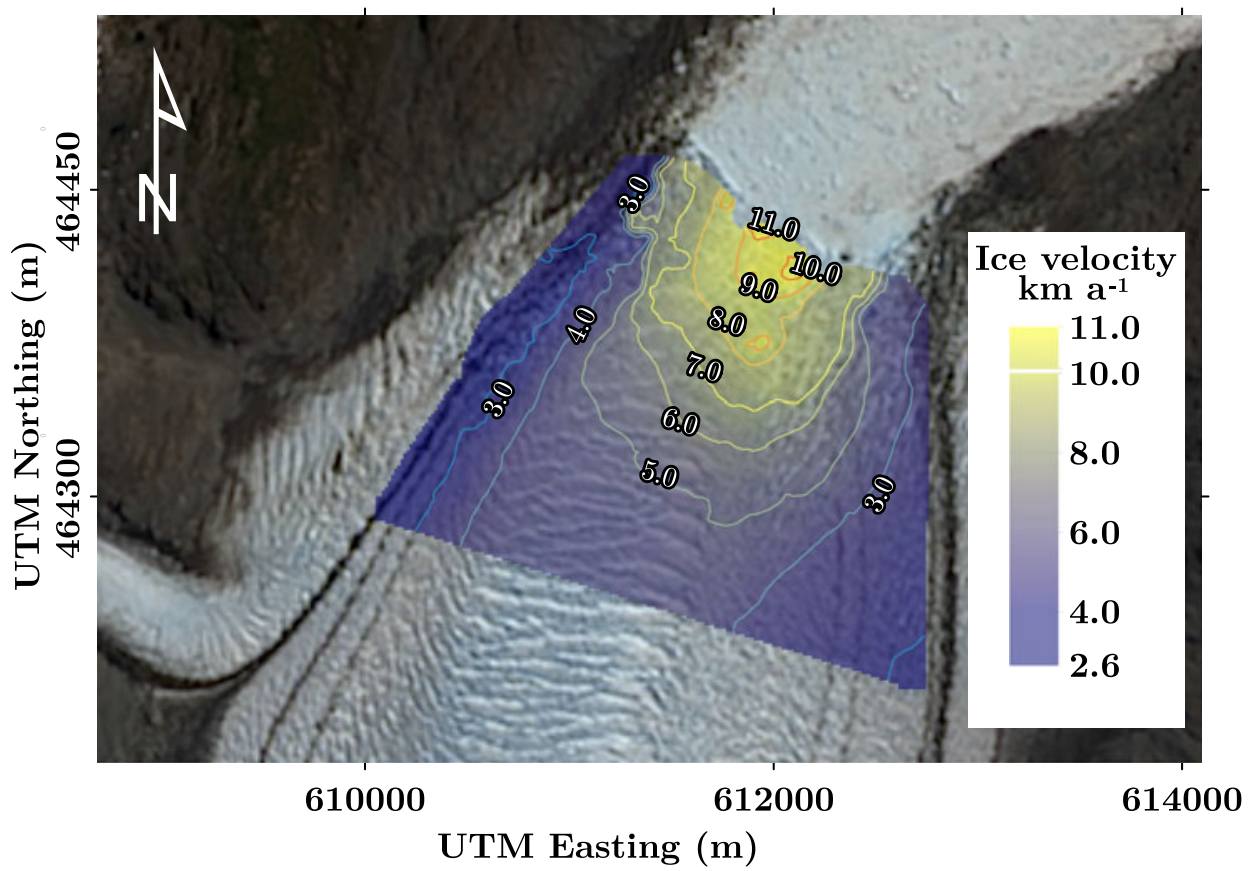

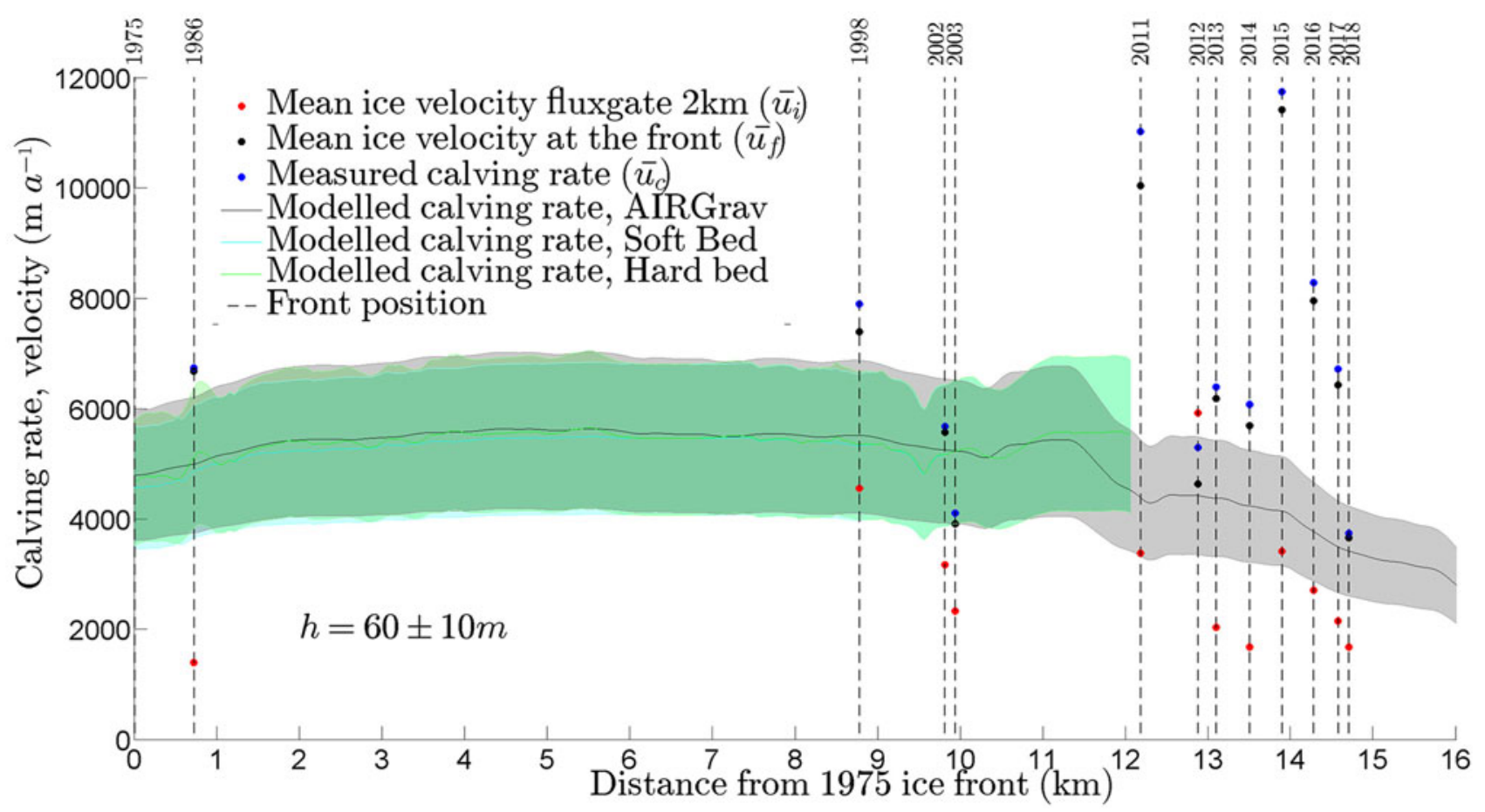

Fig. 8. Ice velocity and calving rate of Jorge Montt Glacier along a longitudinal profile during its retreat. Modelled calving rates were calculated with a relative water depth based parameterisation of Mercenier and others (2018) using subaerial ice cliff height $h$ set to $60 \pm 10 \mathrm{~m}$ and three datasets for bedrock topography (gravimetric measurements, soft and hard bed bathymetry profiling). Soft bed (cyan) is highlighted above hard bed (green) where sediments are present. Note AIRGrav dataset was corrected by Gourlet and others (2016) based on fjord bathymetry measurements presented in this work.

average of $-6.41 \mathrm{~m}$ w.e. $\mathrm{a}^{-1}$ in $2012-2017$ through surface mass balance and calving versus the $-4.64 \mathrm{~m}$ w.e. $\mathrm{a}^{-1}$ in $2011-2017$ solely by ice thinning (Foresta and others, 2018) supports this statement. Methodological issues including spatial resolution, timescales and ice density can also be argued to explain this discrepancy.

It is interesting to compare the frontal velocities and the calving flux of Jorge Montt with other Patagonian glaciers, for example with San Rafael, a tidewater glacier located in the western side of the Northern Patagonia Icefield (Rivera and others, 2007), that has been a focal point of interest due to its extremely high ice flow velocity. Here, velocity reached a maximum of $7.2 \pm 0.4 \mathrm{~km} \mathrm{a}^{-1}$, resulting in a calving flux in 2007 of $2.22 \pm 0.05 \mathrm{~km}^{3}$ (Willis and others, 2012a). These very high numbers are smaller than the $11 \pm 2 \mathrm{~km} \mathrm{a}^{-1}$ maximum ice velocity measured at Jorge Montt front in 2015 and much smaller than the highest frontal ablation obtained in 1998 of $4.74 \pm 1.21 \mathrm{~km}^{3}$. Other SPI lacustrine calving glaciers such as Ameghino (Stuefer, 1999), Grey (Lliboutry, 1956) or Perito Moreno (Warren, 1994) are characterised by much lower ice velocities and calving rates; even in case of the catastrophic retreat of Upsala Glacier in the 1990s its maximum calving velocity reached $1877 \mathrm{~m} \mathrm{a}^{-1}$ 
Accumulation $\square$ Surface melt $\square$ Frontal ablation $\square$ Surface mass balance $\square$ Total mass balance Subglacial discharge/frontal ablation $\square$ Surface melting/frontal ablation

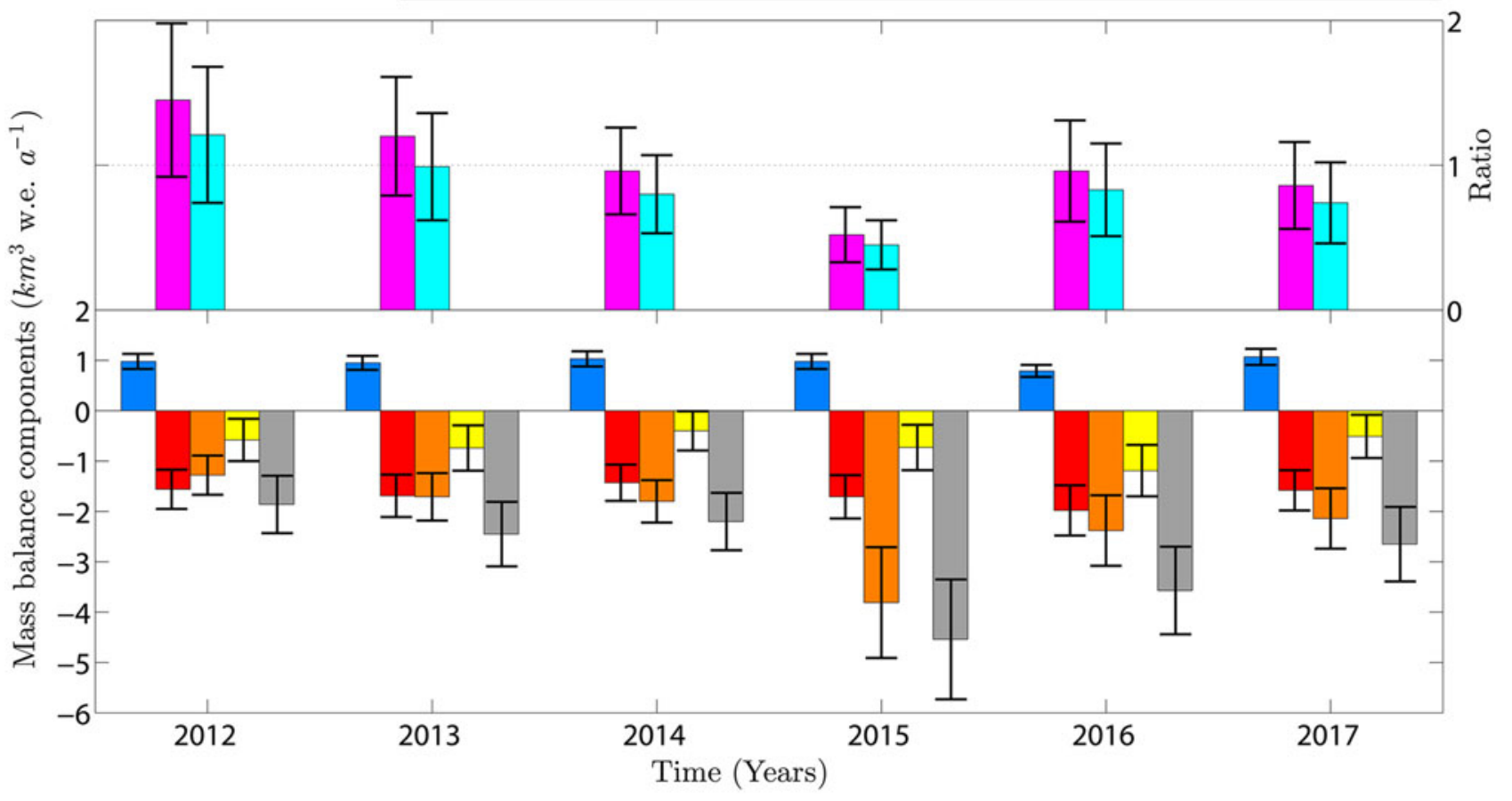

Fig. 9. Mass-balance components of Jorge Montt Glacier in 2012-2017: subglacial discharge to frontal ablation and surface mass balance to frontal ablation ratios in the top panel; accumulation, surface melt, frontal ablation, SMB and TMB in the bottom panel.

(Skvarca and others, 2002), which is almost an order of magnitude less than the maximum values of Jorge Montt. Our estimates place Jorge Montt among the fastest tidewater glaciers in the world.

This negative mass-balance trend took place while snow accumulation at Jorge Montt increased in the long term, between 1980 and 2015 (Bravo and others, 2019a), indicating that climate is not the main driving factor, and that instead, dynamic thinning is the primary control (Mouginot and Rignot, 2015). It is clear that this thinning must have been reinforced by surface processes however, such as a snow deficit as well as melt and meltwater percolation. We tested this relationship by analysing the correlation between surface melt and velocity, but the results were conclusive only in the lowest part of the glacier (Fig. 10), where high velocities were significantly related to surface melt. We found no correlation further upstream.

To explore the impact of fjord geometry on frontal ablation and retreat, we compared the modelled calving rates (Mercenier and others, 2018) with observed frontal ablation and retreat rates (Fig. 8). The model of Mercenier and others (2018) is driven by the relative ice thickness only, disregarding other internal and external factors such as ice flow velocity, ice damage inherited from upglacier crevassing and thermal undercutting. Hence, in Jorge Montt Glacier it can explain the calving component related to the dynamic instability of the front approaching floatation. When observed frontal ablation rate diverges from the modelled value of calving rate we suggest that other factors, such as ice velocity fluctuation driven by a change in mass balance or thermal undercutting, are driving the retreat of the glacier front, which is otherwise at equilibrium at a particular water depth

It is important to explore how the total mass-balance partitioning would follow if subglacial topography conditions change in the future. Assuming that subglacial discharge is equal to the sum of liquid precipitation and surface melt, i.e. that the entire rain and meltwater mass is routed through the englacial and subglacial drainage system and released at the front forming a buoyant plume and enhancing submarine melt, we use the ratio of frontal to surface ablation flux as a simple measure that describes the relative importance of these two main freshwater sinks: iceberg calving that mostly releases fresh water to the surface and shallow ocean layers (Enderlin and others, 2016; Moon and others, 2018), and subglacial discharge, originating mostly from surface melt, that releases fresh water at the fjord bottom (Moffat and others, 2018). Here, the contribution of submarine melt as part of the frontal ablation flux is ignored. We are aware that this may be an oversimplification of the very complicated processes that are involved, but we argue that even with such a simple approach we can provide important clues about the possible future evolution of fjord hydrography. As a result, it appears that if Jorge Montt front retreats to shallow water as expected from AIRGrav bathymetry, most of the fresh water will be sourced from surface melt and will therefore be released subglacially at the front and will increase submarine melt rates. This is similar to modelling results of Amundson and Carroll (2018) that show a small lag between maxima of subglacial discharge and frontal ablation flux during retreat of a tidewater glacier. Simultaneously, iceberg production will diminish and less fresh water will be produced on the fjord surface as a spatially distributed source. Altogether, this might have important consequences on future fjord circulation (Moffat and others, 2018), sediment budget (Syvitski, 1989) and nutrient fluxes (Bhatia and others, 2013). As mentioned before, it is necessary to investigate how subglacial discharge will modulate the submarine melt. Modelling results of Moffat and others (2018) show that the freshwater contribution from submarine melting at Jorge Montt during winter months equals the fresh water sourced from subglacial discharge. In our approach, submarine melting is not strictly separated from calving flux as they are considered in bulk as the frontal ablation flux. Nonetheless, modelled submarine melting rates of Moffat and others (2018) are an order of magnitude lower than our reported calving rates, suggesting 


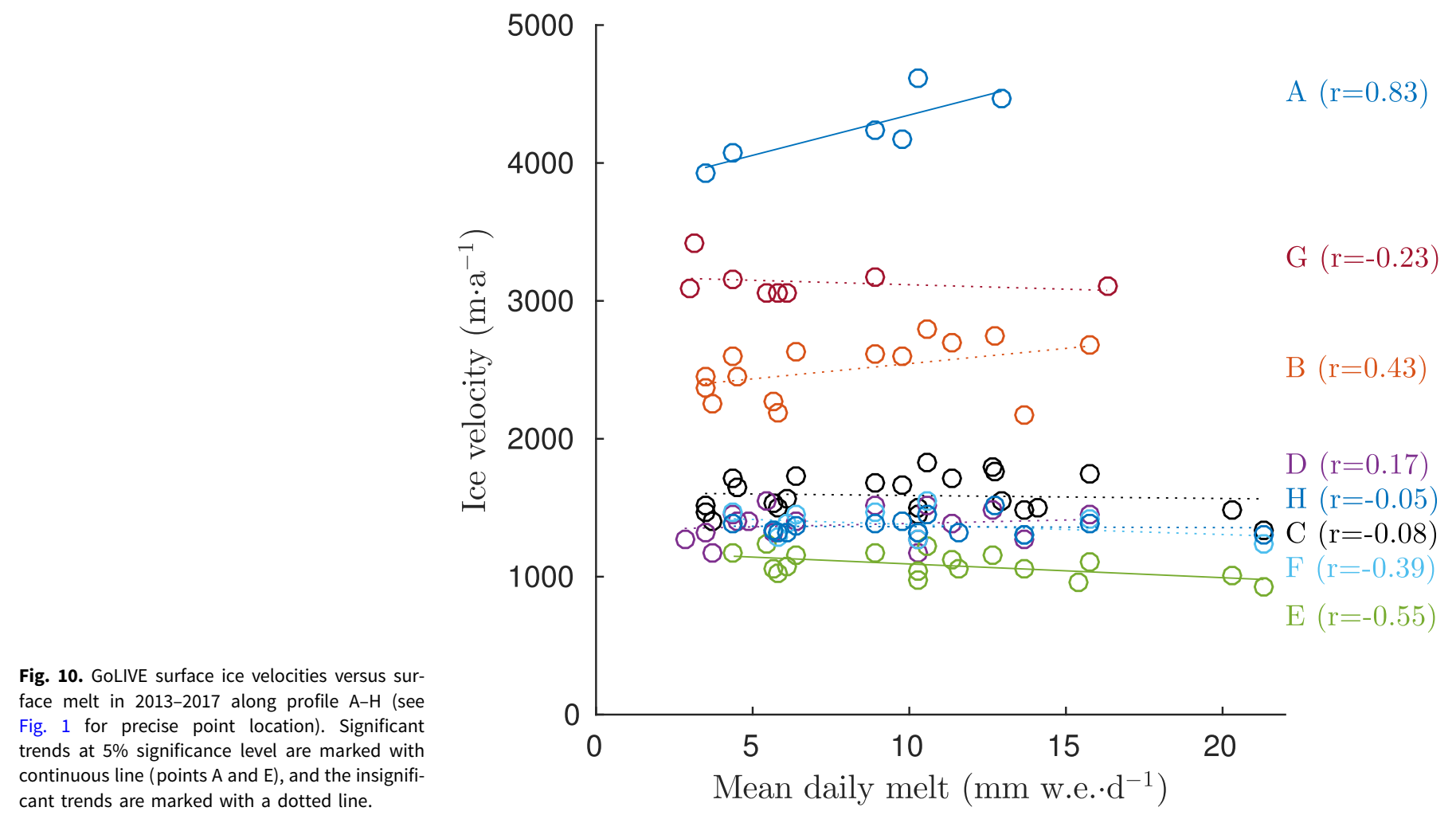

that the impact on the observed retreat is of secondary importance. Still, submarine melting can be an important trigger of calving through thermal undercutting (O'Leary and Christoffersen, 2013). Glacier and ocean modelling may provide a basis to sustain a hypothesis of glacier slow down and a switch into a retreat mode governed by surface slope, similar to observations at the Columbia Glacier (Venteris, 1999; O'Neel and others, 2005).

van der Veen (1996) explained the catastrophic retreat of Columbia Glacier as being driven by the dynamic thinning of the front due to an increase in ice flow velocities. In this case, relative depth at the terminus remained constant adapting to different water depth conditions during retreat. Therefore, the glacier remained close to flotation and calving was not determined by the absolute, but rather by the relative water depth. In such case, our assumption of bounds on $h(60 \pm 10 \mathrm{~m})$ used in the calving rate parameterisation may not only serve as an error estimation, but also shows how calving rate will change when there is a small fluctuation of subaerial cliff height in response to water depth change during retreat. Moreover, wide bounds of plausible calving rates with varying $h$ shown in Figure 8 reflect the ability of the calving front to adapt its calving rate through small changes in ice front geometry that can push the front towards conditions close to approach floating criterion as suggested for temperate glaciers by van der Veen $(1996,2002)$. In this context, the temperate thermal structure of Jorge Montt Glacier not only allows for extremely high ice velocities, but also pushes the glacier towards a higher calving rate by its susceptibility to dynamic thinning at the terminus.

Maxima of the modelled calving rates do not exceed $7000 \mathrm{~m} \mathrm{a}^{-1}$ and are significantly lower than the observed ones (Fig. 8). This difference becomes especially high in recent years (2013-2017) when, according to AIRGrav bathymetry estimates, the glacier front is supposed to have already retreated to a shallower bed (Fig. 6). Such discrepancy can be explained either by the simple structure and/or poor constraints in the model parameterisation of Mercenier and others (2018), or by a possible underestimation of ice thickness in the region where AIRGrav survey has not been directly calibrated and validated with echosounding results (Gourlet and others, 2016). The results of Gourlet and others (2016) have larger uncertainty in constrained, narrow valleys of the outlet glaciers such as Jorge Montt fjord which may have strong implications when ice dynamics is considered. Nonetheless, if the retreat continues into shallower bedrock it can be expected a future decrease in calving rate (Fig. 8) and consequently, a plausible deceleration of frontal retreat. This, however, will also depend on the future oceanic forcing that up to now remains poorly constrained.

\section{Conclusions}

We studied Jorge Montt tidewater glacier with multiple-source datasets including remote-sensing imagery and field data that were analysed together with a mass-balance model. The results suggest a dynamically driven response of the glacier characterised by sustained frontal retreat, high ice velocities and strong calving, altogether resulting in high mass imbalance during this decade. Jorge Montt calving rates obtained in this research are much higher than the rates observed in the other calving glaciers of the SPI. If the ongoing retreat continues, we estimate that the glacier will soon start to slow down, and approach a new and more stable condition due to the presence of bed topography above sea level $\sim 3 \mathrm{~km}$ upstream from the present position.

Supplementary Materials. The supplementary material for this article can be found at https://doi.org/10.1017/jog.2019.47

Acknowledgments. This research was financed by CECs. CECs is a nonprofit research organisation funded by the Basal Finance programme of CONICYT, among others. This paper also acknowledges FONDECYT grant \#1171832. We thank the support of the Water Cadastre of Chile (DGA). Oceanographic data were collected by CECs and University of Concepción, Chile. We thank D. Sakakibara for providing Jorge Montt velocity profiles. C. Bravo acknowledges support from the CONICYT Becas-Chile $\mathrm{PhD}$ scholarship programme. C. Moffat and F. Bown acknowledge support from CONICYT-DRI Grant \#2012-0012. Waters of Patagonia and the crew of 'Don Tito' provided valuable support in the field. We thank chief editor Hester Jiskoot, one anonymous reviewer and Jason Amundson for giving 
valuable comments and recommendations that greatly improved the quality of the article. We appreciate the editions to the manuscript and comments by Duncan Quincey.

\section{References}

Amundson JM and Carroll D (2018) Effect of topography on subglacial discharge and submarine melting during tidewater glacier retreat. Journal of Geophysical Research: Earth Surface 123(1), 66-79.

Bhatia MP and 5 others (2013) Greenland meltwater as a significant and potentially bioavailable source of iron to the ocean. Nature Geoscience 6(4), 274.

Bravo C and 6 others (2019a) Assessing snow accumulation patterns and changes on the Patagonian Icefields. Frontiers in Environmental Science $7(1), 30$.

Bravo C and 6 others (2019b) Air temperature characteristics, distribution and impact on modeled ablation for the South Patagonia Icefield. Journal of Geophysical Research: Atmosphere 124(2), 907-925.

Carrasco JF, Osorio R and Casassa G (2008) Secular trend of the equilibriumline altitude on the western side of the Southern Andes, derived from radiosonde and surface observations. Journal of Glaciology 54(186), 538-550.

Carturan L, Cazorzi F, Blasi FD and Dalla Fontana G (2015) Air temperature variability over three glaciers in the Ortles-Cevedale (Italian alps): effects of glacier fragmentation, comparison of calculation methods, and impacts on mass balance modeling. Cryosphere 9(3), 1129-1146.

Collao-Barrios $\mathbf{G}$ and 7 others (2018) Ice flow modelling to constrain the surface mass balance and ice discharge of San Rafael Glacier, Northern Patagonia Icefield. Journal of Glaciology 64(246), 568-582.

Cuffey KM and Paterson WSB (2010) The Physics of Glaciers, 4th Edn. Oxford: Butterworth-Heinemann.

De Angelis H (2014) Hypsometry and sensitivity of the mass balance to changes in equilibrium-line altitude: the case of the Southern Patagonia Icefield. Journal of Glaciology 60(219), 14-28.

Enderlin EM, Hamilton GS, Straneo F and Sutherland DA (2016) Iceberg meltwater fluxes dominate the freshwater budget in Greenland's icebergcongested glacial fjords. Geophysical Research Letters 43(21), 11-287.

Fahnestock M and 5 others (2016) Rapid large-area mapping of ice flow using Landsat 8. Remote Sensing of Environment 185, 84-94.

Foresta $\mathbf{L}$ and 7 others (2018) Heterogeneous and rapid ice loss over the Patagonian ice fields revealed by CryoSat-2 swath radar altimetry. Remote Sensing of Environment 211, 441-455.

Fountain AG and Walder JS (1998) Water flow through temperate glaciers. Reviews of Geophysics (Washington, D.C.) 36(3), 299-328.

Gardner AS and 10 others (2013) A reconciled estimate of glacier contributions to sea level rise: 2003 to 2009. Science 340(6134), 852-857.

Garreaud RD (2018) Record-breaking climate anomalies lead to severe drought and environmental disruption in western Patagonia in 2016. Climate Research 74(3), 217-229.

Gourlet P, Rignot E, Rivera A and Casassa G (2016) Ice thickness of the northern half of the Patagonia Icefields of South America from high-resolution airborne gravity surveys. Geophysical Research Letters 43(1), 241-249.

Harrison S and 14 others (2018) Climate change and the global pattern of moraine-dammed glacial lake outburst floods. Cryosphere 12, 1195-1209.

Hock R (2005) Glacier melt: a review of processes and their modelling. Progress in Physical Geography 29(3), 362-391.

Jaber A, Wael DF, Johnson E and Rott H (2017) Recent surface elevation changes of Patagonian glaciers derived with TanDEM-X, 2017 IEEE International Geoscience and Remote Sensing Symposium (IGARSS), pp. 2821-2824.

Kalnay E and 21 others (1996) The NCEP/NCAR 40-Year reanalysis project. Bulletin of the American Meteorological Society 77(3), 437-472.

Koppes M, Conway H, Rasmussen LA and Chernos M (2011) Deriving mass balance and calving variations from reanalysis data and sparse observations, Glaciar San Rafael, northern Patagonia, 1950-2005. Cryosphere 5(3), 791-808.

Lenzano MG and 6 others (2018) Analyzing the oscillations of the Perito Moreno Glacier, using time-lapse image sequences. Cold Regions Science and Technology 146, 155-166.

Leprince S, Barbot S, Ayoub F and Avouac J-P (2007) Automatic and precise orthorectification, coregistration, and subpixel correlation of satellite images, application to ground deformation measurements. IEEE Transactions on Geoscience and Remote Sensing 45(6), 1529-1558.
Lliboutry L (1956) Nieves y glaciares de Chile. Santiago Fundamentos de glaciología. Ediciones de la Universidad de Chile.

Malz P and 5 others (2018) Elevation and mass changes of the Southern Patagonia Icefield derived from TanDEM-X and SRTM data. Remote Sensing 10(2), 188

Mercenier R, Lüthi MP and Vieli A (2018) Calving relation for tidewater glaciers based on detailed stress field analysis. Cryosphere 12(2), 721-739.

Millan R and 11 others (2019) Ice thickness and bed elevation of the Northern and Southern Patagonian Icefields. Geophysical Research Letters 46(12), 6626-6635

Moffat C (2014) Wind-driven modulation of warm water supply to a proglacial fjord, Jorge Montt Glacier, Patagonia. Geophysical Research Letters 41(11), 3943-3950.

Moffat C and 6 others (2018) Seasonal evolution of ocean heat supply and freshwater discharge from a rapidly retreating tidewater glacier: Jorge Montt, Patagonia. Journal of Geophysical Research: Oceans 123(6), 4200-4223.

Moon T and 5 others (2018) Subsurface iceberg melt key to Greenland fjord freshwater budget. Nature Geoscience 11(1), 49.

Mouginot J and Rignot E (2015) Ice motion of the Patagonian Icefields of South America: 1984-2014. Geophysical Research Letters 42(5), 1441-1449.

Muto M and Furuya M (2013) Surface velocities and ice-front positions of eight major glaciers in the Southern Patagonian ice field, South America, from 2002 to 2011. Remote Sensing of Environment 139, 50-59.

O'Leary M and Christoffersen P (2013) Calving on tidewater glaciers amplified by submarine frontal melting. Cryosphere 7(1), 119-128.

O'Neel S, Pfeffer WT, Krimmel R and Meier M (2005) Evolving force balance at Columbia Glacier, Alaska, during its rapid retreat. Journal of Geophysical Research: Earth Surface 110(F3), F03012 (doi: 10.1029/ 2005JF000292)

Pfeffer WT (2007) A simple mechanism for irreversible tidewater glacier retreat. Journal of Geophysical Research: Earth Surface 112(F3), F03S25 (doi: 10.1029/2006JF000590).

Pfeffer WT and 18 others (2014) The Randolph glacier inventory: a globally complete inventory of glaciers. Journal of Glaciology 60(221), 537-552.

Radić V and Hock R (2011) Regionally differentiated contribution of mountain glaciers and ice caps to future sea-level rise. Nature Geoscience 4(2), 91.

Rasmussen LA, Conway H and Raymond CF (2007) Influence of upper air conditions on the Patagonia Icefields. Globaland Planetetary Change 59(1-4), 203-216.

Rignot E, Rivera A and Casassa G (2003) Contribution of the Patagonia Icefields of South America to sea level rise. Science 302(5644), 434-437.

Rivera A, Benham T, Casassa G, Bamber J and Dowdeswell JA (2007) Ice elevation and areal changes of glaciers from the Northern Patagonia Icefield, Chile. Global and Planetary Change 59(1-4), 126-137.

Rivera A, Corripio J, Bravo C and Cisternas S (2012a) Glaciar Jorge Montt (Chilean Patagonia) dynamics derived from photos obtained by fixed cameras and satellite image feature tracking. Annals of Glaciology 53(60), $147-155$.

Rivera A, Koppes M, Bravo C and Aravena JC (2012b) Little ice age advance and retreat of Glaciar Jorge Montt, Chilean Patagonia. Climate of the Past 8(2), 403-414.

Sakakibara D and Sugiyama S (2014) Ice-front variations and speed changes of calving glaciers in the Southern Patagonia Icefield from 1984 to 2011. Journal of Geophysical Research: Earth Surface 119(11), 2541-2554.

Scambos T, Fahnestock M, Moon T, Gardner A and Klinger M (2016) Global Land Ice Velocity Extraction from Landsat 8 (Go-LIVE), Version 1, Boulder, Colorado USA.

Schaefer M, Machguth H, Falvey M, Casassa G and Rignot E (2015) Quantifying mass balance processes on the Southern Patagonia Icefield. Cryosphere 9(1), 25-35.

Skvarca P, De Angelis H, Naruse R, Warren CR and Aniya M (2002) Calving rates in fresh water: new data from southern Patagonia. Annals of Glaciology 34, 379-384.

Stuefer M (1999) Investigations on Mass Balance and Dynamics of Moreno Glacier Based on Field Measurements and Satellite Imagery (Ph.D. thesis, University of Innsbruck, Austria).

Syvitski JPM (1989) On the deposition of sediment within glacier-influenced fjords: oceanographic controls. Marine Geology 85(2-4), 301-329.

Takeuchi Y, Naruse R and Skvarca P (1996) Annual air-temperature measurement and ablation estimate at Moreno Glacier, Patagonia. Bulletin of Glaciological Research 14, 23-28. 
van der Veen CJ (1996) Tidewater calving. Journal of Glaciology 42(141), 375-385.

van der Veen CJ (2002) Calving glaciers. Progress in Physical Geography 26(1), 96-122.

Venteris ER (1999) Rapid tidewater glacier retreat: a comparison between Columbia Glacier, Alaska and Patagonian calving glaciers. Globaland Planetary Change 22(1-4), 131-138.

Wake LM and Marshall SJ (2015) Assessment of current methods of positive degree-day calculation using in situ observations from glaciated regions. Journal of Glaciology 61(226), 329-344.

Warren CR (1994) Freshwater calving and anomalous glacier oscillations: recent behaviour of Moreno and Ameghino Glaciers, Patagonia. Holocene 4(4), 422-429.
Warren CR and Sugden DE (1993) The Patagonian Icefields: a Glaciological Review. Arctic and Alpine Research 25(4), 316-331.

Willis MJ, Melkonian AK, Pritchard ME and Ramage JM (2012a) Ice loss rates at the Northern Patagonian Icefield derived using a decade of satellite remote sensing. Remote Sensing of Environment 117, 184-198.

Willis MJ, Melkonian AK, Pritchard ME and Rivera A (2012b) Ice loss from the Southern Patagonian ice field, South America, between 2000 and 2012. Geophysical Research Letters 39(17), L17501 (doi: 10.1029/2012GL053136).

Wilson R and 6 others (2018) Glacial lakes of the Central and Patagonian Andes. Global and Planetary Change 162, 275-291.

Wilson R, Carrión D and Rivera A (2016) Detailed dynamic, geometric and supraglacial moraine data for Glaciar Pio XI, the only surge-type glacier of the Southern Patagonia Icefield. Annals of Glaciology 57(73), 119-130. 